\title{
Arrangement of Authority for Investigators of the National Drug and Food Control Agency (BPOM) in Law Enforcement in the Field of Drugs, Food and Beverages
}

\author{
Surung Malem Karo Sekali, Sudarsono, I Nyoman Nurjaya \& Abdul Rachmad Budiono \\ Brawijaya University, Faculty of Law, Malang, INDONESIA
}

Received: 30 January 2020 • Accepted: 12 May 2020 • Published Online: 30 May 2020

\section{Abstract}

\begin{abstract}
Some of the problems faced by the National Drug and Food Control Agency (BPOM) in carrying out their duties, include philosophical problematic of the BPOM's authority as a drug and food supervisor, does not seem to provide a tendency for justice but has the potential to reverse, theoretical problems with the regulation of BPOM's authority in the form of a Presidential Regulation, and juridical problematics, namely the lack of synchronization regarding the authority of BPOM. The purpose of this research is to analyze the regulatory authority of BPOM in law enforcement in the fields of medicine, food and beverages. This research uses normative legal research methods with the statute approach, and conceptual approach. The analytic technique of this research is using evaluative analysis. The results showed that BPOM investigators' authority can be carried out with 2 (two) schemes, namely strengthening the authority of BPOM investigators and forming institutions for preventing and eradicating criminal acts in the field of medicine and food, including elements of BPOM, Police and Prosecutors, which regulate the speedy judicial process.
\end{abstract}

Keywords: National Drug and Food Control Agency (BPOM), regulation, authority, investigations.

\section{Introduction}

The establishment of the National Food and Drug Control Agency (BPOM) is an institutional realization in guaranteeing the protection of consumer rights and as a technical implementer of the laws and regulations above. BPOM was established based on Presidential Decree No. 103/2001 concerning Position, Duties, Functions, Authority, Organizational Structure, and Work Procedures of Non-Departmental Government Institutions. Before the existence of BPOM, the function of drug and food control was also carried out by the Directorate General of Drug and Food Supervision under the Ministry of Health, as outlined in Decree of the Minister of Health of the Republic of Indonesia Number 130/Menkes/SR/I/2000 concerning organization and work procedures of the Ministry of Health, which conveys one of the duties and functions of the Directorate General of Drug and Food Control, exercises authority in the field of drug and food control. Then after the reformation, the existence of the role of the Director General of Drug and Food Control was established by a new agency to become BPOM which was determined to be a Non-Departmental Government Institution (LPND) to carry out the functions and duties of drug

(C) Authors. Terms and conditions of Creative Commons Attribution 4.0 International (CC BY 4.0) apply. Correspondence: Surung Malem Karo Sekali (Doctoral Candidate), Brawijaya University, Faculty of Law, Malang, INDONESIA. E-mail: surungmalemfhub@gmail.com. 
and food control which were previously carried out by the Directorate General of Drug and Food Control.

others:

In the context of drug and food control carried out by BPOM constrained, among

\begin{abstract}
a. "Legislation (Health Law, Consumer Protection Act, Narcotics Act, Psychotropic Law, and implementing regulations) has not fully supported national policies in the field of drug and food control".

b. "Differences in interpretation of laws and regulations that apply in the field of medicine and food, causing conflicts of norms or ambiguity of norms in their implementation which results in less effective supervision of drugs and food".

c. "The authority of Civil Servant Investigator (PPNS) BPOM has not been supported by a set of norms which are contained in a special law governing drug and food control, so there is no maximum investigation into drug and food criminal acts". d. "Cross-sectoral coordination is not optimal, especially at the regional level in drug and food surveillance".

e. "The scope of work of drug and food supervisors covers all provinces and districts/cities throughout Indonesia, while BPOM only has UPT organizations at the provincial level”.

f. "The involvement of international crime networks in the fields of medicine and food".
\end{abstract}

Potentials that can pose a threat from drug and food crimes in addition to the main problems for health, also have an impact on the economy in the country, these impacts can be demonstrated by the loss or reduction of tax revenues and import duties and will lead to depressed competitiveness in the business world. Long-term potential for security and order in society including national security. "The Head of the Police Criminal Investigation Agency Commissioner General Ari Dono Sukmanto together with BPOM guards in Bogor on 22 August 2016 stated that preventing the circulation of illegal food was one of the focuses of the Police and BPOM" (Tempo.co, 2016).

Organizational restructuring efforts to accelerate the handling of drug and food crime cases and harmonization with law enforcement institutions, was shown in 2018 BPOM recruited three new directors in security and intelligence from the State Intelligence Agency (BIN), the Attorney General's Office, and the National Police Headquarters. The filling of this position is to strengthen BPOM's capacity in preventing cross-border drug and illegal food distribution.

The investigation function carried out by BPOM in its implementation must still coordinate with the National Police to file a filing which is then carried out the file submission to be prosecuted by the prosecutor from the Public Prosecutor's Office, so that the existence of the role of BPOM is only limited to investigation, for that a scientific study is needed in the case of BPOM's authority more broadly in the process of law enforcement, this is in line with the implementation of the function of the criminal justice system for law enforcement, which gives BPOM authority in investigations and even independent prosecutions. With this study, it aims to find the ideal law, as written by Satjipto Rahardjo, that legal products are not final, but which must be continuously built (law in making), so that renewal or legal formation is needed by looking at the needs of the community (Rahardjo, 2008).

From the description above, we can catch that there are several philosophical problems to be investigated, namely among others ontologically, epithymologically, and axiologically from the existence of this BPOM. Based on the ontology aspect, which is the essence that the existence of food, drinks and medicines requires supervision in order to maintain safe, healthy and quality food so that consumption of food and medicine is maintained and healthy human quality achieved both short and long term for the development of the Indonesian nation. In terms of epithymology or methods in achieving quality food, drinks and medicines that are 
quality and safe, it requires supervision and prosecution of anyone who is cheating on food and drugs, especially in taking action by giving authority to make BPOM part of criminal justice system. As for the axiology or the benefits of the existence of the BPOM later is to be able to take maximum action for actions that can be snared maximally in law enforcement, because the ability of BPOM in mastering the problem is quite deep, so it can ensnare legally and participate in preventing crime in the field of food and medicine.

Based on the descriptions above, the researcher wants to find out and analyze the regulatory authority of BPOM in law enforcement in the fields of medicine, food and drink.

\section{Research method}

This type of research is normative juridical research, normative legal research or also called doctrinal law research (Amirudin, 2012; Asikin, 2012). In this type of research, the law is conceptualized as what is written in the legislation (law in books) or the law is conceptualized as a rule or norm which is a benchmark of human behavior that is considered appropriate (Ibrahim, 2011). The research approach used is the statute approach and conceptual approach. The legal material from normative research can be divided into three, namely,

1. Primary legal material, legal material that is authoritative consisting of statutory regulations, official records or minutes in the making of legislation and decisions of judges, which are relevant to the legal issues of this study (Marzuki, 2011);

2. Secondary legal law, obtained from publications on laws that are not official documents. Publications about this document include textbooks, legal journals, and comments on court decisions; and

3. Tertiary law materials are legal materials that provide an understanding of primary and secondary legal materials, including legal and political dictionaries, encyclopedias, empirical data, and others.

The technique of searching primary and secondary legal materials is done by studying literature and internet searching (Rahardjo, 2000). The analysis technique in this research is evaluative analysis, which is an analysis that provides justification for the results of the study, the researcher will provide an assessment of the results of the study, whether the hypothesis of the proposed legal theory is accepted or rejected (Rahardjo, 2000).

\section{Results and discussion}

\subsection{Basis for BPOM regulation through Presidential Regulation}

Based on the philosophical basis for regulating the health sector, namely the 1945 Constitution of the Republic of Indonesia through the basic norms of Article 28H paragraph (1), that:

"Every person has the right to live in physical and spiritual prosperity, to live, and to have a good and healthy living environment and the right to health services".

Further efforts in fulfilling human rights to health were formed in health legislation, the latest being replaced with Law Number 36 of 2009 on health, this was also emphasized in the preamble (philosophical basis) which contained that:

"Health is a human right and one of the elements of well-being that must be realized in accordance with the ideals of the Indonesian people as intended in the Pancasila and the 1945 Constitution of the Republic of Indonesia”.

Then also stated in the provisions of Article 4, that "Every person has the right to health". The right to health referred to in that article is the right to obtain various forms of state 
efforts in the realization of health, both health services from health service facilities through hospitals, as well as various state institutions that strive to guarantee the right of citizens to get good and healthy. To support the Government's performance as an effort to realize these philosophical values, based on empirical (sociological) conditions, BPOM is held to carry out the Government's function in controlling drugs, food and beverages.

Based on these provisions, the basis of PERPRES No. 80 of 2017 is a philosophical provision of the 1945 Constitution of the Republic of Indonesia. Based on the order of the laws and regulations, the position of BPOM was formed by a type of Presidential Regulation, hierarchically the laws in Indonesia are regulated through Law Number 10 of 2004 concerning the Formation of Regulations that have been replaced with Law Number 12 of 2011 concerning Formation Regulation of Legislation, contained in Article 7:

1. The 1945 Constitution of the Republic of Indonesia;

2. Decree of the People's Consultative Assembly;

3. Government Act/Regulation in Lieu of Law;

4. Government regulations;

5. Presidential decree;

6. Provincial Regional Regulations; and

7. Regency/City Regulations.

In addition, Article 8 of Law Number 12 of 2011 concerning Formation Regulation of Legislation also regulates the types and hierarchy of other laws and regulations, which reads as follows:

Types of legislation other than Article 7 paragraph (1) include regulations established by the People's Consultative Assembly, the House of Representatives, the Regional Representative Council, the Supreme Court, the Constitutional Court, the Supreme Audit Board, the Judicial Commission, Bank Indonesia, Ministers, agencies, institutions, or commissions of the same level formed by Law or Government on the orders of the Law, Provincial Regional Representative Council, Governor, Regency/City Regional Representative Council, Regent/Mayor, Village Head or equivalent.

Legislation as referred to paragraph (1) is recognized and has binding legal force insofar as it is ordered by a higher statutory regulation or formed based on authority. Based on the provisions above, the Presidential Regulation has a hierarchical basis or sequence of rules and regulations. Bagir Manan writes that every statutory regulation must have a legal basis in the higher-level regulations (Manan, 2004).

Based on the Indonesian legal structure, the provisions of the BPOM in the Presidential Regulation then became the basis for the formation of policies underneath which were formed by administrative officials, also still based on the Staatsfundamentalnorm namely Pancasila which was affirmed in the Opening of the 1945 NRI Constitution, then Staatsgrundgesetz namely the 1945 Constitution Body, Formell Gesetz namely Constitution.

The establishment of BPOM, namely through a Presidential Regulation, compared to other institutions established by law, has a stronger position in the wider scope of authority. Procedural provisions can then be formed with the head regulation as a policy regulation. The making of policy regulations is needed in order to ensure the consistency of administrative actions. This compliance does not only apply to actions that originate from or are based on statutory regulations, it also applies to actions that are based on freedom of action, including the principle of equality (gelijkheidsbeginsel), the principle of legal certainty (rechtszekerheidsbeginsel) and the principle of trustworthiness (vertrowenbeginsel). With the existence of these policy regulations, it will be guaranteed compliance with state administrative actions and for each event 
that contains equality, legal certainty, and actions can be trusted because it is based on certain regulations.

\subsection{Strengthening BPOM's Authority through Law Products}

Some previous studies show the weakness of supervision and law enforcement by BPOM, more and more illegal food/drinks/cosmetics are found that threaten people's safety.

"Data on cases of illegal drug criminal acts from 2010 to 2016 also showed that only $52.11 \%$ entered the investigation stage; $32.39 \%$ prosecution stage; and $11.27 \%$ of court proceedings, but efforts to recommend follow-up actions on BPOM findings are still given to the Health and Police Services. The results of drug control in 2015 showed that there were $19.53 \%$ of district/city pharmaceutical service facilities and pharmaceutical installations that did not meet the requirements. Of the 5,553 recommendations of the POM Agency for local governments, only $18.10 \%$ were followed up with court decisions which were considered by various parties to not have a deterrent effect. Under the Health Act, producers and distributors of illegal drugs will be charged under Article 196 through Article 198 with a maximum penalty of 15 years imprisonment and a maximum fine of Rp1.5 billion. But what has happened so far is that the highest court decision is only in the form of eight months' imprisonment with a Rp5 million fine in Medan" (Yuningsih, 2016).

In recent times, BPOM has become the most highlighted institution because it is considered weak in the supervision of drug distribution. Previously, many similar cases were troubling the public, including cases of fake vaccines, fake drug factories and expired drug cases. So that raises the desire to strengthen the POM to be more effective in overseeing the circulation of drugs and food. Some DPR members stated that the weakness in strengthening BPOM's authority was motivated by BPOM's weak supervision performance. Irma Suryani Chaniago, member of the House of Representatives Commission IX, stated that:

"So far, even though BPOM has been assigned to oversee the distribution of medicines and food, they have been unable to do anything. When BPOM discovers dangerous food and medicines, the agency can only submit findings to the police. They cannot oversee the continuation of drug and food distribution irregularities, because these weaknesses of authority are often suspects who should be fined, jailed for their cheating, receive light sanctions and some are just released" (Triyono, 2018; Rosalina, 2016).

In addition, Dede Yusuf, Chair of the House of Representatives Commission IX, said:

"The formulation of the Drug and Food Control Bill is generally carried out to protect the public from the distribution of dangerous food and drugs. The formulation of the Act is still in its early stages and all sorts of points contained in the draft are likely to be subject to change. Specifically for BPOM, there is indeed a desire for authority from upstream to downstream, but we realize this is not easy because there is a Ministry of Trade, Ministry of Industry, Police, National Police, so we ask for input from many parties."

The plan to strengthen BPOM received support from House of Representatives Commission IX Member Irma Suryani Chaniago explained that:

"If BPOM is given the authority to take action to impose sanctions. Strengthening can give authority to BPOM to provide sanctions. Because, so far BPOM only oversees the circulation of drugs. When there are findings, BPOM only publishes without any follow-up. Meanwhile, the findings are given to the police. BPOM must have a legal basis (Law) to strengthen its function and authority. I support the additional authority of BPOM. The rise of cases that have arisen lately shows that increasing authority for BPOM is very urgent. BPOM must be given the authority to 
investigate such as the KPK. This is because BPOM's authority is more preventive by only conducting unannounced inspections and not being able to conduct seizures and investigations. Many drug and food cases have passed because BPOM cannot oversee the legal process. During this time, if there are findings from BPOM, the case is submitted to the police for handling. In fact, the punishment of drug dealers and counterfeit drug makers and does not create a deterrent effect. At this point, the Amendment to the Law on BPOM is urged to give full spectrum oversight authority to BPOM so that it can carry out supervision from upstream (registration to post production) to downstream (post market). Previously, in the bill related to BPOM, the willingness of pharmacy and drug control had been inserted. So now the House of Representatives Commission IX says BPOM must have its own law. At present, the DPR has proposed a bill on Drug and Food Control through the Legislative Body (Baleg). However, because the discussion process of the old bill while the case is urgent, Irma hopes the President will issue a Presidential Regulation first. The presidential regulation is expected to provide additional authority for BPOM while waiting for the completion of the law that is now rolling in the DPR" (Rafael, 2018; Winarto, 2018).

These various empirical conditions require strengthening of BPOM's authority in supervision and law enforcement through strengthening the types of laws and regulations. If regulated in the Law, the PPNS enforcement authority has clarity, legal certainty, and legal force.

In essence BPOM shows as a body that has its own field and also has an important function in conducting order, legal certainty and circulation of drugs, food and drinks. Therefore, the provisions of BPOM as "rules of the game" in addition to containing the value of legal certainty, also contain elements of justice and usefulness, this is because BPOM in carrying out its functions and duties has implications for the ongoing supervision of drugs, food and beverages. Noting the legal implications above, the renewal of investigative law by BPOM can be displayed in the following table.

Tabel 1. Direction of BPOM legal renewal

\begin{tabular}{|c|c|c|c|}
\hline No. & Type & Content & Updates/Improvements \\
\hline \multirow[t]{8}{*}{1} & \multicolumn{3}{|c|}{ Presidential Regulation No. 80 of 2017} \\
\hline & & Types of Presidential Regulation & Law/Mandate BPOM in the Act \\
\hline & & Position & $\begin{array}{l}\text { Describe the position to carry out the } \\
\text { tasks of the Government }\end{array}$ \\
\hline & & Duties, Functions, and Authority & Content in the Law \\
\hline & & Authority of investigation & $\begin{array}{l}\text { A description of the scope of authority } \\
\text { and position with the Police }\end{array}$ \\
\hline & & Judicial Process & Quick justice \\
\hline & & Prosecution & Prosecution authority \\
\hline & & Coordination Procedure & $\begin{array}{l}\text { 1. The law regulates in general, spelled } \\
\text { out in technical regulations by } \\
\text { ensuring the establishment of } \\
\text { BPOM regulations } \\
\text { 2. Establishment of new technical } \\
\text { regulations }\end{array}$ \\
\hline \multirow[t]{3}{*}{2} & \multicolumn{3}{|c|}{ BPOM Regulation on Organization and Working Procedure of BPOM } \\
\hline & & Organizational structure & $\begin{array}{l}\text { Description of the technical provisions } \\
\text { of the organizational structure }\end{array}$ \\
\hline & & $\begin{array}{l}\text { The authority of investigation, } \\
\text { prosecution, coordination and justice } \\
\text { is fast }\end{array}$ & $\begin{array}{l}\text { More detailed description based on the } \\
\text { mandate of the Act }\end{array}$ \\
\hline
\end{tabular}

Renewal of the legal content above is needed for legal certainty which is expected to be able to improve order, which leads to justice, considering the function of law in development is as a means of community renewal, this is based on the assumption that there is order in development, is something that is considered important and very is required. Theo Huijbers 
stated that the function of law is to preserve the public interest in society, protect human rights, realize justice in living together. These three goals are not contradictory, but constitute the filling of one basic concept, namely that humans must live in a society, and that the community must be well regulated (Huijbers, 1982).

Observing the increasingly developing role of BPOM with the development of types of crime, it needs to be balanced with various forms of regulations that must be directed to the purpose of the law, BPOM regulation must aim to avoid various problems that will arise from all aspects of functional units. Formation of laws and regulations in the context of harmonizing responsive legal laws, is carried out through a democratic and integrated process which is guided by Pancasila and sourced in the 1945 Constitution of the Republic of Indonesia, to produce harmonious laws and regulations up to the level of implementing regulations. Formation of laws and regulations that must pay attention to the provisions that fulfill philosophical values with core sense of justice and truth, sociological in accordance with the cultural values prevailing in society, and juridical values in accordance with the provisions of applicable laws and regulations.

Structuring a comprehensive and integrated national legal system, it is important to harmonize the law with the intention of structuring and adjusting elements of the national legal order, by placing a mindset that underlies the formulation of a national legal system framework that is imbued with Pancasila and the 1945 Constitution. referred to, intersect with the target program of the formation of laws and regulations, namely the creation of harmonization of laws in accordance with the aspirations of the community and development needs.

The structuring and adjustment of the elements of the national legal system and the renewal of national laws, especially general and neutral legal fields, are efforts in the context of harmonizing the law. The field of law as a legal basis for dealing with change. As a foundation and problem in dealing with all of that, steps can be overcome and taken by harmonizing law and practice through efforts to develop legal regulations proposed through one of the government agencies.

To maintain synchronization between the Perpres and national development policies, the application of the principle of "lex superior derogat legi inferiori" has become a fundamental requirement. This principle results in the law having a higher position removing the law under it, or in other words the lower level law must be in accordance with the provisions above it (Marwan, 2011). Although in this case, it is emphasized that the use of this principle must also take into account aspects of equality with the specificity of the Perpres based on the principle of "lex specialis derogat legi generali". However, what needs to be underlined is that the Presidential Regulation is a technical provision that further regulates the provisions of the law above it.

\subsection{Strengthening BPOM's authority in the integrated Criminal Justice System}

The criminal justice system is often interpreted narrowly as "a court system that administers justice on behalf of the state or as a mechanism to resolve a case/dispute" (Arief, 2008). Furthermore, Barda Nawawi Arief, said that the understanding is in the narrow sense, because it only sees from the structural aspects of the "system of courts" as an institution and from the aspect of power to judge/resolve cases (administer justicela mechanism for the resolution of disputes). The justice system is essentially identical to the law enforcement system, because the judicial process is essentially a process of enforcing the law. The Criminal Justice System is known as the SPP or Criminal Justice System/CJS, in essence a Criminal Law Enforcement System (SPHP), is identical to the judicial power system in the field of Criminal Law (SKK-HP). 
Criminal law enforcement is carried out through criminal justice processes based on criminal procedural law (KUHAP. Law No. 8 of 1981). Speaking of criminal law enforcement, it is impossible to break away from talking about the criminal justice system, as a system that operates criminal law in real terms.

The judicial system or law enforcement system, hereinafter referred to as $\mathrm{SPH}$, is seen as an integral, integrated unit of various sub-systems (components) consisting of components of legal substance, legal structure, and legal culture. As a system of law enforcement, the judicial process/law enforcement is closely related to those three, namely legal norms/legislation (substantive/normative component), institutions/structures/law enforcement officers (structural/institutional component and procedural/administrative mechanisms - trait), and legal cultural values (cultural component). What is meant by the values of legal culture (legal culture). In the context of law enforcement, of course, it is more focused on the values of legal philosophy, legal values that live in society and awareness/attitudes of legal behavior/social behavior, and education/legal science (Arief, 2008).

Integrated Criminal Justice System (SPP) covering:

1. The criminal justice system (SPP) is essentially identical to the criminal law enforcement system (SPHP). The system of "law enforcement" is basically a "system of power/authority to enforce the law". The power/authority to enforce this law can also be identified with the term "judicial power", therefore, SPP or SPHP is essentially identical to the "Judicial Power System in the field of Criminal Law" (SKKHP).

2. SPP which is essentially a "system of enforcing criminal law" or "a system of judicial power in the field of criminal law", is manifested implied in 4 (four) subsystems: (1) the authority of the investigator (by the agency/investigative institution); (2) power of "prosecution" (by public prosecuting bodies/institutions); (3) the power of "adjudicating and passing judgment/penalties" (by a court); and (4) powers of "enforcement of decisions/penalties" (by executing/executing bodies/apparatus). The four stages/subsystems constitute an integral whole of the criminal law enforcement system or often referred to as "SPP (Integrated Criminal Justice System)”.

Based on the understanding of the justice system (SPH) it can be seen from various aspects: Judging from the aspect/component of legal substance, the justice system is essentially a substantive system of law enforcement (in the field of criminal law covering material criminal law, formal criminal law, and criminal law of criminal conduct), this is an "integrated legal system" or integrated legal substance. The use of criminal law to settle a criminal case is actually a criminal law enforcement. Criminal law enforcement is a process to turn legal (criminal) desires into reality.

According to Satjipto Rahardjo, what is referred to as legal desires here is none other than the thoughts of the legislature formulated in the legal regulations (Rahardjo, 2006). Meanwhile, according to Loebby Loqman, law enforcement activities are first intended to improve order and legal certainty in society. In the framework of this endeavor, the coordination and improvement of tasks between law enforcement agencies will be strengthened. This is done, among others, by disciplining the functions, duties, powers, and authorities of the institutions tasked with enforcing the law according to the proportions of each scope, and based on a good system of cooperation (LoebbyLoqman, 2001).

The criminal justice system is actually a criminal law enforcement process. In the criminal justice system process there are various law enforcement agencies which are components or sub-systems of criminal justice. According to V. N. Pillai (1978) criminal justice system can be interpreted as follows: 
"By the criminal justice system is meant the police, the prosecutorial services, the courts and correctional departments, which are the component elements of the structure of the criminal process, and it has been describe as a continuum and orderly progression of event."

Furthermore, Muladi said, the meaning of an integrated criminal justice system was synchronization or harmony and harmony. Synchronization can be distinguished by structural synchronization, substantial and cultural (Herbert, 1978). Structural synchronization is the synchronization and harmony of the framework of relations between law enforcement agencies (police-prosecutors-courts-correctional institutions), while the substantial synchronization is the existence of vertical and horizontal synchronization and harmony in relation to positive law. While cultural synchronization, namely the existence of harmony and harmony in living the views, attitudes and philosophies that thoroughly underlie the running of the criminal justice system.

However, completely relying on the settlement of criminal cases or handling crime in the field of drugs and food on the utilization of criminal law is not appropriate. The ability of criminal law has limitations as said by Donald R. Taft and Ralph W. England (1964), that:

"The effectiveness of criminal law cannot be measured accurately. Law is only one means of social control. Habits, beliefs, religion, group support and criticism, emphasis from interest groups and the influence of public opinion are more efficient means of regulating human behavior than legal sanctions."

Seen from the other side, that the settlement of cases through criminal justice (penal) has many weaknesses. Among them, the settlement of cases attached to the justice system is very long (the delay inherent in a system) in ways that are very detrimental, namely wasting time, expensive costs, making people hostile (enemies), questioning other times, not solving problems the future and paralyze the parties (Harahap, 1997). Vago said that:

In relation to the criminal justice process creating hostility between the parties, Steven

"Judicial resolution of individual dispute's also effects the distribution of values. Some people gain, others lose, some individuals are honoured, others are stigmatized, and as with all types disputes, a court decision seldom resolves the underlying condition for conflict."

Meanwhile, Barda Nawawi Arief identified (2008) the causes of the limited ability of criminal law in tackling crime:

1. The causes of such crimes are beyond the scope of criminal law;

2. Criminal law is only a small part (subsystem) of the means of social control that is impossible to overcome the problem of crime as a very complex human and social problem (as a socio-psychological, socio-political, socio-economic, socio-cultural, etc.);

3. The use of criminal law in overcoming crime is only a curier am symptom, therefore criminal law is only a "symptomatic treatment" and not a "causative treatment";

4. Criminal law sanctions are "remedium" which contain contradictory/paradoxical nature and contain negative elements and side effects;

5. Criminal system is fragmental and individual/personal, not structural/functional;

6. Limitations of types of criminal sanctions and the formulation of criminal sanctions systems that are rigid and imperative;

7. The operation/functioning of criminal law requires supporting facilities that are more varied and more demanding "high costs".

Joseph Goldstein (1976) distinguish criminal law enforcement into three parts. Namely: first, "total enforcement", namely the scope of criminal law enforcement as formulated 
by substantive criminal law. This total criminal law enforcement is not possible, because law enforcers are strictly limited by criminal procedural law which includes the rules of arrest, search, confiscation and preliminary examination.

In the process of implementing criminal law enforcement in the health sector in a consistent and consistent manner, it is necessary to increase the quality of the apparatus that is responsible, professional and proportional, disciplined as well as providing adequate supporting infrastructure through strengthening the authority of BPOM investigators, implementing and enforcing the law in a strict and straightforward manner, but humane based on the principles of justice and legal certainty. This is important considering that the health sector is an important instrument in achieving the country's goals.

In examining the strengthening of the authority of investigators BPOM can be understood as one form of policy or crime prevention efforts (criminal policy) which is essentially an integral part of efforts to protect society (social welfare) therefore it can be said that, the main objective of criminal politics is protection community to achieve community welfare (Arief, 2008).

All aspects of life and state power are determined by the rules of the state administrators and the guidelines for the rules of the state administration which are called the law as a norm of rules that are agreed upon and universally applicable, besides that in society there are rules that live and develop as guidelines for living together. Then in the criminal justice system as a system in the framework of law enforcement it contains systemic motion between sub-systems or functional components which include the Police, Attorney's Office, Courts and Penitentiary to each other is one unity (totality) which is always related and coordinated and seeks to transform input into output to achieve the goal of the criminal justice system or the criminal justice system.

In implementing the criminal justice system, the systemic motion between the functional components that are related to each other and is a totality needs to exist within the framework of criminal law enforcement purposes. According to William Friedman (1984), criminal law enforcement is strongly influenced by 3 elements or components, as "elements of legal system", namely the legal structure, legal substance, and legal culture.

The three components influence each other in law enforcement efforts. Whereas law as substance is the result or "output" of the system itself, in this sense it includes laws and regulations, doctrines, and regulations used by the organizer in carrying out its duties and authorities.

Legal culture by Friedman is defined as values and attitudes that have to do with the legal system, and which will have an effect, both positive and negative, on behavior related to law, he said, other elements in the system are cultural. These are values and attitudes which bind the system together and ethic determine the place of the legal system in the culture of the society as a whole. That is, values and attitudes will bind the system together and determine the place of the system itself in the culture of society as a whole.

Understanding of the legal culture of society, cannot be separated from archer on the culture of society as a whole, given that the law is part (sub-culture) of the culture of society, in the perspective of legal culture, law can be seen more realistic, not limited to the content and legal institutions that are there is only, but as it is the law in people's lives. This means that the law is obeyed or not obeyed, used or avoided, even abused or misuse of the law, legal culture, Friedman said, is the driving force for the operation of law (court) in society. Whether or not a court works is highly dependent on the legal culture of the community (Sidmen, 1978).

In law enforcement, it cannot be separated from the police. According to Sadjijono (2008), the duties and authority of the police are as follows: 
"The ability of the police profession is grouped in the main tasks of the police, namely: (a) maintaining security and public order, (b) enforcing the law, and (c) providing protection, protection and service to the community, which then in carrying out these basic tasks broken down into tasks and authorities, both in general and specifically."

When seen the ability of the police and the scope of their duties, the police are considered capable of solving various problems in the community, but in reality there are still weaknesses. According to Alfons Loemau et al. (2005), "the police is a living rule of law, meaning that the law will remain as a death letter if the police do not act in the name of the law to be enforced".

The use of criminal law to settle criminal cases is actually criminal law enforcement. Criminal law enforcement is a process to turn legal (criminal) desires into reality. Satjipto Rahardjo referred to as legal desires here is none other than the thoughts of the legislature formulated in the legal regulations. Satjipto Rahardjo (2006) and Loebby Loqman (2001) said that law enforcement activities were first intended to improve order and legal certainty in society.

In the framework of this endeavor, the coordination and improvement of tasks between law enforcement agencies will be strengthened. This is done, among others, by disciplining the functions, duties, powers, and authorities of the institutions tasked with enforcing the law according to the proportions of each scope, and based on a good system of cooperation. In carrying out its duties and functions, BPOM cannot run alone, it requires cooperation or partnership with other stakeholders. In the era of regional autonomy, especially related to the health sector, the role of regions in developing development plans and policies has a very big influence on the achievement of national goals in the health sector.

\section{Conclusion}

Law Number 36 of 2009 does not strengthen the authority of BPOM investigators in law enforcement in the field of drugs, food and beverages with consideration of the authority of the investigation held by the National Police as a law enforcement agency in the criminal justice system, the authority of law enforcement is contained in the 1945 Constitution of the Republic of Indonesia, the authority in the criminal justice process is listed in the Criminal Procedure Code as the main criminal procedure law and the National Police Act which also states the authority of law enforcement and investigation. Future arrangements for the authority of BPOM investigators can be done with 2 (two) schemes. First, strengthening the authority of BPOM investigators through the establishment of a law that clearly states the authority of BPOM investigations to provide strength and legal certainty. Second, the law can establish institutions for the prevention and eradication of criminal acts in the field of drugs and food in which there are elements of BPOM, the Police and Prosecutors Office, which regulates the speedy judicial process.

The 1945 Constitution of the Republic of Indonesia NRI determines the National Police as an element of the state that functions as law enforcement, then the Criminal Procedure Code as the main criminal procedure law determines the authority of the National Police investigator in the process of working on criminal law, but in addition it is also given the authority of PPNS in conducting investigations with restrictions still having to coordinate with investigators of the National Police, so Law No. 36 of 2009 also provides space for PPNS in law enforcement in the field of medicine and food. This authority needs to be strengthened in the law given that the field of medicine and food is one of the basic needs which is the main element of national security. The Government and the Parliament need to immediately ratify the Draft Drug and Food Law which contains the substance of strengthening the enforcement authority through investigations by BPOM investigators, the substance containing the main tasks, authorities, and responsibilities, 
the coordination mechanism with Police and Prosecutors investigators, thus, any BPOM findings can reach criminal justice processes.

\section{Acknowledgements}

This research did not receive any specific grant from funding agencies in the public commercial, or not-for-profit sectors.

The authors declare no competing interests.

\section{References}

Amirudin \& Asikin, Z. (2012). Pengantar metode penelitian hukum [Introduction to legal research methods]. Jakarta: Rajawali Press.

Arief, B. N. (2008). Reformasi sistem peradilan (Sistem penegakan hukum di Indonesia) [Judicial system reform (Law enforcement system in Indonesia)]. Semarang: Badan Penerbit, Universitas Diponegoro.

Donald, R. T., \& Ralph, W. E. (1964). Criminology, New York, Macmillan Co.

Fajar, M., \& Achmad, Y. (2010). Dualisme Penelitian Hukum Normatif-Empiris [Dualism of normativeempirical law research]. Yogyakarta: Pustaka Pelajar.

Goldstein, J. (1976). Criminal justice, law and politics. Masaachusetts: Duxburg Press.

Harahap, M. Y. (1997). Beberapa tinjauan mengenai sistem peradilan dan penyelesaian kasus [Several reviews regarding the judicial system and case resolution]. Bandung, Citra Aditya Bakti.

Herbert, L. P. (1978). The limits of the criminal sanction. Stanford: Stanford University Press.

Huijbers, T. (1982). Filsafat hukum dalam lintasan sejarah [Legal philosophy in historical paths]. Bandung: Kanisius.

Ibrahim, J. (2011). Teori dan metodologi penelitian hukum normatif [Theory and methodology of normative legal research]. Malang: Bayumedia Publishing, Cet.ke-4.

Lawrence, M. F. (1984). American law. New York: W.W. Norton \& Company.

Loebby Loqman (2001). Kapita selekta tindak pidana di bidang perekonomian [Capita selekta criminal acts in the economic field]. Jakarta: Datacom.

Loemau, A. et al. (2005). Penegakan hukum oleh polisi: Studi kasus Hendra Rahardja [Law enforcement by the police: Case study of Hendra Rahardja]. Jakarta: Restu Agung.

Manan, B. (2004). Teoridan politikkonstitusi, Cetakan kedua [Political theory and constitution, Second edition]. Yogyakarta: FH UII Press.

Marwan, M. (2011). Pengantar ilmu hukum, Cet. Ke-1 [Introduction to legal studies]. Bogor: Ghalia Indonesia.

Marzuki, P. M. (2011). Penelitian hukum [Legal research]. Jakarta: Kencana Prenada Media. (2006). Masalah penegakan hukum [Law enforcement problems]. Suatu Tinjauan Sosiologis, BPHN. Bandung: Sinar Baru.

(2008). Membedah hukum progresif, Cet.Ke-3 [Dissecting progressive law]. Jakarta: Penerbit Buku Kompas. 
Pillai, V. N. (1978). An approach to the crime correction in the developing countries. Report for 1978 and Resource Material Series, Number 16, UNAFEI, 1978.

Rafael, E. C., \& Winarto, Y. (2018). DPR minta BPOM diberikan kewenangan penindakan [DPR asks BPOM to be given enforcement authority]. Jakarta: kontan.co.id. Available at https://nasional.kontan.co.id/news/dpr-minta-bpom-diberikan-kewenangan-penindakan, accessed on 29 January 2019

Rahadjo, S. (2000). Ilmu hukum [Legal studies]. Bandung: Citra Aditya Bhakti.

Sadjijono (2008). Etika profesi hukum [Legal professional ethics]. Yogyakarta: Laksbang Mediatama.

Seidman, R. (1978). The state, law and development. New York. St Martin's Press Inc.

Triyono, A., \& Rosalina, D. (2018). Draf RUU Pengawasan Obat dan Makanan menyebut BPOM akan diberi kewenangan penyidikan [The Draft Bill on Drug and Food Control said that BPOM would be given the authority to investigate]. Jakarta: Kontan.co.id. Available at https://nasional.kontan.co.id/news/draf-ruu-pengawasan-obat-dan-makanan-menyebutbpom-akan-diberi-kewenangan-penyidikan, accessed on 29 January 2019.

Tempo.co (2016). Polri-BPOM kerja sama ungkap kasus makanan dan obat ilegal [The National PoliceBPOM collaborates on food and drug cases].

http://m.tempo.co/read/news/2016/o8/22/063797815/porli-bpom-kerja-sama-ungkapkasus-makanan-dan-obat-ilegal. Accessed 15 July 2017.

Yuningsih, R. (2016). Upaya penguatan pengawasan obat [Efforts to strengthen drug supervision]. Majalah Info Singkat, Pusat Penelitian Badan Keahlian DPR RI, Vol. VIII, No. 18/II/P3DI/September/2016.

http://news.metrotvnews.com/read/2018/03/29/852502/bpom-rekrut-pejabat-polri-hingga-bin. accessed on 10 July 2018. 
S. Malem Karo Sekali et al. - Arrangement of Authority for Investigators of the National...

C O A $\mathrm{s}$ 